\title{
The effect of Myanmar's foreign investment policies on FDI inflows: An analysis of panel data across ASEAN member countries
}

\author{
Miguel D. Ramirez*,Blake Tretter \\ Department of economics, Trinity College, Hartford, Ct 06106 \\ *Corresponding author E-mail: Miguel.Ramirez@trincoll.edu
}

\begin{abstract}
Once one of the richest countries in Southeast Asia, Myanmar suffered the effects of a closed economy for over 50 years and became one of the poorest and most corrupt countries in the world. Though excited international investors wait to exploit Myanmar's large labor force and natural resources as it reopens its markets, the country is currently far behind its potential. In such a small economy, large FDI inflows could have a significant impact on the country's path going forward. Whether or not it receives these inflows depends on how multinational enterprises view Myanmar's investment environment. In particular, its recently enacted foreign investment law as well as the status of sanctions on the country. By looking at a cross-section of ASEAN-member countries for the period 1995-2011, this paper analyzes the effect of foreign investment policies on FDI flows using a panel fixed-effects regression.
\end{abstract}

Keywords: Foreign direct investment (FDI), fixed effects model (FEM), foreign investment law (FIL), hausman test, index of economic freedom, OLI framework, random effects model (REM), and multinational enterprises (MNES).JEL classifications: o11, o52, c23, and f210.

\section{Introduction}

Before the socialist takeover, Myanmar had become one of the richest countries in Southeast Asia amidst the political unrest (see [1]). Prior to 1962, Myanmar and Thailand, two bordering countries, had similar sized populations and levels of GDP. In the following 50 years their populations grew at similar rates, while Thailand's economy grew to over five times the size of Myanmar's (Worldbank.org). The lack of growth in Myanmar is attested by its low GDP per capita of just US\$875.1, which translates to an extremely poor quality of life. Rich in natural resources and favorably located in the Bay of Bengal, one of Asia's major shipping regions, Myanmar had much potential. It even became a world leader in rice exports signifying its importance in regional agriculture. Yet, 50 years under the rule of its ruthless military junta brought Myanmar's progress to a standstill and it quickly fell behind its neighbors. To this day, Myanmar still appears to be stuck in the 1960s and is known globally as one of today's least developed countries.

2010 marked Myanmar's initial steps towards its first civilian government since 1962. With hopes of encouraging this momentum, many countries have either waved or given extensions on debts owed to them by Myanmar. Additionally, many non-governmental and intergovernmental organizations have promised financial assistance during Myanmar's transition. For instance, the World Bank and the Asia Development Bank have either announced plans to, or have already provided grants to Myanmar that intend to help the country repay debts or develop its infrastructure. Though the sustainability of these reforms remains in question, multinational enterprises (MNEs) and individual investors alike believe the country has substantial upward potential as its economy begins to open up to the rest of the world. In addition to Myanmar's many attractive qualities for investors, two of Myanmar's five bordering countries, China and India, contain the two largest and fastest growing economies in the world (see [2]).

Attraction of foreign investors can be explained through John Dunning's OLI framework (also known as the Eclectic Paradigm) in which he argues that firms look for three strategic advantages in a host country. These relative advantages are in the form of Ownership, Location, and Internalization (explained in greater detail in the next section). Myanmar's success in further securing foreign capital most likely depends upon two specific factors. One factor is the openness of its foreign investment laws and the government's ability and transparency in enforcing these laws. The second factor is the status of international sanctions that, in turn, depend upon the transparency and accountability of the government as well as the ongoing ethnic and religious conflicts the country has been plagued with. These laws and sanctions, until only recently, changed on a daily basis. 
After ten months of strenuous negotiations, the government of Myanmar designed and enacted a foreign investment policy that aims to attract investment from abroad while simultaneously protecting the interests of domestic firms. In designing the law, Myanmar's government and President considered two main factors. Notably, the first factor is to protect the people and the economy of the host country. However, if a set of policies is geared too disproportionately toward domestic firms without benefits to foreign firms, the second factor, viz., attracting foreign direct investment, would be unsuccessful. Fortunately, Myanmar has had the ability to learn from fellow ASEAN member countries in their past experiences of attracting FDI. ASEAN member countries have benefitted greatly from FDI and their investment policies have evolved around this development.

Furthermore, the degree to which capital and knowledge reach the people of Myanmar could determine the success of a full transition to a democracy and open market economy, or at least keep Myanmar from reverting back to its old ways. Myanmar has been presented with an incredible opportunity. Now known by many as the final frontier in Southeast Asia, international awareness could translate into capital that would significantly impact the growth of its underdeveloped economy. However, Myanmar must first prove to be a worthy destination of investment to attract capital and knowledge. By analyzing the institutional determinants of FDI flows to other ASEAN member countries, Myanmar should adjust its own policy according to the successes and failures of its neighbors.

The paper is organized as follows. Section I examines Dunning's OLI framework. Section II provides a deeper insight into the main topic of the paper, Myanmar's Foreign Investment Law. Section III outlines the econometrics analysis, while the panel (fixed-effects) results and main conclusions are presented, respectively, in Sections $1 \mathrm{~V}$ and V.

\section{The OLI framework}

In his framework known as the Eclectic Paradigm, or the OLI-Framework, John Dunning believes a host country must satisfy three basic fundamentals to attract FDI. They are Ownership, Location, and Internalization (see [3]). The OLI framework is applicable in the case of Myanmar as well as in other ASEAN member countries. Because the three relative advantages of Ownership, Location, and Internalization can be found in many cases throughout the country, Myanmar should theoretically attract FDI. However, as discussed in the introduction with reference to the ASEAN countries, the presence of these components are only relevant provided that foreign investors are not restricted from investing.

In the case of Ownership, explained as the rights and protection of intangible assets such as copyrights and trademarks, Myanmar is far behind. As reported in the Herbert Smith Freehills' Myanmar investment guide, the only functional law in place is the Copyright Act of 1914, which has not been updated for application to contemporary issues. Although Myanmar has been a member of the WTO since 1995 and is a participant of the TRIPS agreement, which provides protection of intellectual property to other WTO members, Myanmar has been granted a grace period for the implementation of these laws through the end of 2013. Similarly, there are few laws protecting trademarks or patents. Though trademarks can be registered during the registration process with MIC thereby providing some protection against particular claims, the registration alone does not provide any sort of absolute guarantee of protection. With respect to patents, there are no laws that offer protection to modern standards. Under these conditions, firms utilizing more advanced techniques or technologies may refrain from bringing these methods to Myanmar altogether. This impedes potential efficiency on the part of the foreign firm and is a loss of potential technology of which Myanmar could benefit. Though minimal, other laws do exist that provide some protection with respect to intellectual property, however, it is clear that Myanmar in general does not meet international standards.

On the other hand, locational advantages might prove to be the most promising component insofar as Myanmar is concerned. First, firms looking to invest in Myanmar may be attracted by the proximity to developing markets where they can find low-cost labor and sell their products. Myanmar's sizable population of over 50 million people whom will be looking to become consumers will require jobs. Because of the lack of education in Myanmar, these jobs will consist of more labor-intensive roles and require mainly low-skilled and low-wage labor. These qualifications are the beginning of a sequence of development that is commonly seen across much of Southeast and East Asia. Though the proximity to potential markets does not seem as relevant today as increasingly more goods are being shipped to their final destination rather than being manufactured nearby as previously discussed (see [4]), this sizable population will increasingly become comprised of consumers looking to purchase goods and services.

Also, foreign firms are often attracted to developing countries such as Myanmar in view of their stock of natural resources. Though the government has been largely funded from the extraction of natural resources over the years, the country's intention to join the EITI should decrease the level of corruption in the industry and increase confidence for foreign firms. Myanmar has significant established reserves of both onshore and offshore natural gas and oil, rare earth metals, and a substantial teak industry. The teak industry, known historically for its poor treatment of its labor force, has caused the implementation of sanctions by the US specifically against this industry. 
Furthermore, foreign firms may find locational advantages through the host country's investment policy. Myanmar's ASEAN membership and overall need to promote foreign investment will lead to lower tariffs (as described in the ASEAN CEPT agreement) and tax incentives. The government's approach will be to provide lower tariffs to those firms that decide to operate within special economic zones. According to the Special Economic Zone Law (2011) and Dawei Special Economic Zone Law (2011), these areas provide investors with various incentives and benefits such as tax reliefs to qualified investors (see [5]). Many investors not interested or not able to invest in these zones due to irrelevance will still receive tax breaks for an initial period of time when upfront costs are greatest and risks are highest. It is through these promotions that Myanmar is attempting to compensate for other difficulties involved in investing in its country. Again, depending on the specific asset in which foreign firms are interested will ultimately decide on their decision to invest however, investors who may find similar assets and conditions in other countries may be attracted to Myanmar with these incentives.

The presence of Dunning's final component, internalization, was less apparent until the completion of the 2012 FIL in November 2012. Drafts of the law required that a foreign firm enter into a partnership or joint venture with a domestic partner, provide minimum levels of capital, and rent land from a local partner. Fortunately, the final law is not as strict. For one, there are no requirements forcing foreign firms to enter into joint ventures, there are no capital requirements, and foreign investors can lease land without a domestic partner for up to 50 years, with the option to extend by two additional 10-year periods. Under these new circumstances and providing that the investment is approved by MIC (explained in the next section), a firm will be able to invest in Myanmar on a more direct basis. Therefore, the firm will have the ability to further internalize their operations and therefore be more compelled to invest.

With the further development and modernization of policies, firms will find Myanmar improving their laws on intellectual property. They are the locational advantages where most firms will seek the greatest rewards. Lastly, the advantages firms will find through internalization will be an added benefit, and certainly one that was previously unexpected. Though more specific analysis of the new foreign investment law may rescind or add to the advantages discussed above, it would appear that Myanmar currently satisfies the better parts of two of the three components.

\section{Myanmar's foreign investment law}

Firms are always looking for the next hotspot where labor is less expensive than its neighbors or markets have not yet been saturated with similar products. International firms are extremely excited as they consider Myanmar to be the "last frontier" in Southeast Asia, and globally, with respect to economic development (see [6]). The authors of the International Enterprise of Singapore report argue, "It is the last sizeable economy and market in Asia that remains untapped." While the presence of Dunning's components is vital, Moran [7] believes it is the overall investment environment that will play the biggest role.

A potential misconception at this point is that foreign investment is alien to Myanmar and vice versa. Though attention has surrounded the most recent set of laws put in place in November of 2012, Myanmar first introduced a foreign investment policy in 1988 (the 1988 FIL). The policy aimed to attract foreign investment to energize the private sector. However, because sanctions from the US, EU and other developed countries have limited trade with Myanmar, the majority of the investment it has received has been from other developing countries. The lack of capital from developed countries limited investments in Myanmar to smaller capital projects or large projects that involved the government, which lacked transparency. Though Myanmar has been limited in the amount of foreign capital it received, neighboring countries such as China and Thailand have been investing in Myanmar for quite some time. For instance, Thailand imports much of its natural gas from Myanmar and China has been logging much of the northern region.

Prior to the most recent investment law of 2012, Myanmar put in place the Special Economic Zone Law of 2011 (SEZL) as well as the Dawei Special Economic Zone Law of 2011 (DSEZL), which provide foreign investors with further incentives such as tax reliefs and allow for a range of business activities providing the investors compliance with the specific regulations (Herbert Smith Freehill Myanmar Investment Guide). Myanmar enacted the Foreign Investment Law of 2012 (the 2012 FIL) on November 2nd, 2012. Long awaited, the policy took 10 months and many drafts between the government and President Thein Sein before approval. As stated in the unofficial translation of Myanmar's most recent investment policy, Myanmar hopes to develop much of its economy through the development and exploitation of its natural resources. Furthermore, economic development should benefit its own people while allowing foreign firms to enjoy the surplus with the help of the 2012 FIL. This set of regulations is governed by a newly instituted Myanmar Investment Commission (MIC), which includes relevant personnel from existing government institutions. The Ministry of National Planning and Economic Development (MNPED) compensates these personnel on a salary basis, which should remove some of their incentive to approach their jobs in a corrupt manner. With sanctions currently suspended and likely discontinued in the near future, most of the attention has turned to its newly enacted foreign investment policy.

In addition to the 2012 FIL, the Ministry of National Planning and Economic Development (MNPED) issued the "FIL Rules" in January 2013. These rules provide further detail with respect to regulations broadly described in the 2012 FIL. 
For instance, it repeats the requirements related to foreign ownership with added detail clarifying sector-specific regulations (see [8]). The areas to which this set of rules applies are restricted businesses, conditional investments and investment impact assessments. In its explanation of restricted sectors, a key characteristic is the considerable length of restricted sectors for full foreign ownership compared with those involving joint ventures or minority holdings.

While it is the MNPED, which designs the policies, it is the (MIC), a division of MNPED that enforces the policy and organizes investment in Myanmar including reviewing investment proposals. MNEs looking to invest in the country must comply and complete a 3-step process. First, the company must submit an application to MIC to acquire a MIC permit, followed by an application to DICA, another division of MNPED, to conduct business, and finally registering with the Companies Registration Office (CRO). Regulated by the 2012 FIL, and more specifically the rules, are the specific sectors in which foreign investors cannot conduct business. Most countries across ASEAN have switched to a negative list rather than a positive list. In the case of Myanmar, MIC and the State-Owned Economic Enterprises Law of 1989 (SOEEL) provide an additional list of sectors where investment by individuals other than the government is restricted. However, the investment guide continues to explain that the SOEEL does permit investments in such restricted sectors on a case-by-case basis providing that the investment is through a joint venture with the state, or, if independently by an individual, is consistent with the interests of the state. However, to invest in these sectors often requires special permission by the relevant ministries and the Central Bank of Myanmar (CBM).

\section{Econometrics analysis}

Literature written on the determinants of FDI flows generally concentrates on the macroeconomic and institutional factors of the country or region. In these studies, investment policies are often incorporated through the different tax rates and levels of government spending undertaken by the countries in question. However, because this analysis is designed to concentrate on the effects of the laws themselves, variables must be designed to capture the effect of particular laws. A straightforward approach to studying the effect of specific laws would be to include dummy variables for the enactment of each law. For instance, if a country had a law in place, the value of the variable would equal 1 and if it did not implement that law, the variable would equal zero.

Unfortunately, two major issues that arise with this approach render this method relatively ineffective. The first issue is the lack of variation across such a large number of independent variables. Foreign investment policies often consist of hundreds of regulations, most of which are similar but still oftentimes vary only slightly. How would one differentiate dummy variables for land ownership of $70 \%$ versus $30 \%$ by foreigners through a dummy variable? How would one capture the difference in capital requirements by multinational enterprises in a partnership with a domestic firm? With this many variables, each with a value of either 0 or 1 , and many changing during the same year as countries revise or enact entire investment policies, the data would not generate enough variance for the variables to reveal significant relationships to the dependent variable.

Second, the laws themselves are not always enforced consistently by the governments in question, therefore the specific policy would be misrepresented in its effect on capital flows. In this case, not only would there be insufficient variation across the independent variables, but the little variation that would exist is not always reliable. To solve for these issues, variables must be used that account for these inefficiencies. Ideally, the variables would capture the impact of these laws, their revisions on a yearly basis, and the degree to which they are enforced in a way that is consistent across countries but that also generates a sufficient amount of variation. Fortunately, the Index of Economic Freedom, an index generated and published by The Heritage Foundation and the Wall Street Journal, captures the essence of the regulations imposed by the country in combination with the efficiency with which they are enforced by that country's government. By using an index such as the Index of Economic Freedom, the issues mentioned above are accounted for because the countries are graded on both the policies that are in place, as well as the efficiency and consistency with which the government enforces those policies. Furthermore, the grades given on the ten different components of economic freedom range from 0 to 100 thus generate a much larger range of variation.

The Index of Economic Freedom grades countries on the openness of their economies. The Heritage Foundation provides a framework and methodology that allows for identifying fluctuations in a country's score to specific changes in their policies. Countries are graded from 0 to 100on a culmination of 4 "pillars" which can be broken down further into ten different categories. It then takes the grades from each component and calculates an equally weighted average for the country's overall economic freedom. Using these categories to represent the laws allows for more variation and is a consistent and reliable set of grades that date back to 1995, allowing for fluctuation across time as well.

As with any study with imperfect data, and especially for emerging markets, some issues with this approach remain. For instance, the index's analysis generally looks at data and conditions anywhere from 6 months to 1.5 years prior to the year the study is published. This means that policy changes occurring in 2005 will not be reflected until the 2006 or 2007 index therefore some degree of lag is needed to more accurately reflect changes in FDI flows resulting from changes in policies and governance. Another unfortunate issue is the reliability of the methodology as it pertains to 
emerging markets. For instance, the index's freedom from corruption component is based on Transparency International's Corruption Perceptions Index. Derek Tonkin, a member of the Advisory Board of Hong Kong-based investment and advisory company Bagan Capital and the Chairman of the website www.NetworkMyanmar.org, argues that the TI's index is not always as reliable with respect to ASEAN countries as may be perceived. Tonkin ([9]) delves deeper into the most recent grade given to Myanmar as it was surprisingly given the 172nd place out of 176 rated countries, the same rating given to Myanmar prior to the government reforms. He argues that Myanmar's unfortunate grade is due to a disproportional amount of weight given to the unfortunate human rights violations rather than the recent economic and political advances.

With improvements in the construction of the variables themselves (in this case the use of an established index), of course, comes with some limiting factors. The reality is that while these difficulties will be accounted for as efficiently as possible, these types of misunderstandings in the specific methodologies of the index could prove to be a limiting factor. Furthermore, economic factors and country-specific dummy variables such as the size of the economy, the presence of conflict (mostly ethnic in Myanmar), and whether sanctions are or were in place will be necessary to represent the factors, which the index does not reflect.

\section{Empirical model}

Following the lead of De Mello, Jr. ([10]) and Ramirez ([11]), we estimate a general FDI function with the following arguments:

FDIRGDP=f (RGDP, REX, STDEV_REX, ECONFREE (PROPRIGHT, CORRPTFREE, FISCFREE, GOVSPEND, BIZFREE, LABRFREE, MNTRFREE, TRDFREE, INVESTFREE, FINFREE), CONFLICT, ECONSANC)

Where:

Dependent variable: FDIRGDP: The ratio of FDI inflows to real GDP.

Independent variables: The determinants of foreign direct investment in this model can be grouped into three different categories:

\section{Economic indicators:}

Logrgdp (-1): The log of the lagged real GDP. $\beta_{\mathrm{RGDP}}>0$ : As market size increases in the host country, MNEs have more consumers of their products. The GDP is lagged for two reasons, the first is because firms are not able to know the level of the GDP until after an economic period, and it is even longer before they make the decision to invest. The second reason is to avoid reverse causation with the dependent variable.

Logrex (-2): The log of the lagged real exchange rate (where 100=2005 dollars). The real exchange rate calculated as: (host country official exchange rate (LCU per US\$, period average) x host country consumer price index $(2005=100)$ ) / US Consumer price index $(2005=100) \beta_{\mathrm{REX}}<0>$ : As the real exchange rate either appreciates or depreciates, MNEs can be affected in indeterminate ways. A depreciation of the real exchange rate should make an investment project less expensive and exports from the country more desirable thereby attract foreign firms to conduct business. However, this same fluctuation may also cause the exports to be less profitable in dollar terms thereby decreasing overall profits to the firms. On the other hand, an appreciation of the real exchange rate would cause an investment project to be more expensive for a foreign firm yet they would benefit from higher profits. A two period lag is imposed on the variable to avoid any reverse causality between the real exchange rate, real GDP and FDI inflows.

Stdev_rex (-2): The lagged standard deviation of the real exchange rate. Calculated as: the variance of the yearly

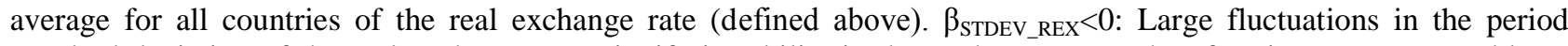
standard deviation of the real exchange rate signify instability in the exchange rate. Therefore investors are unable to accurately predict real profits thereby increasing uncertainty surrounding an investment in the host country. A two period lag is imposed on the variable to avoid any reverse causality between the real exchange rate, real GDP and FDI inflows.

FDI (-1): lagged net FDI inflows. Included to account for persistence or path dependency effects.

\section{Economic freedom:}

PROPRIGHT: Score the host country received for its property rights. $\beta_{\text {PROPRIGHT }}>0$ : The existence and enforcement of property rights that efficiently protect the assets of domestic and foreign firms should reduce the risk of losing those assets.

Corrptfree: The score the host country received for its freedom from corruption. $\beta_{\text {CORRPTFREE }}>0$ : As the level of corruption within the government falls, or in this case, the score based on freedom from corruption increases, more firms will invest in the country.

Fiscfree: The score the host country received for its fiscal freedom. $\beta_{\text {FISCFREE }}>0$ : A measure of taxes in the host country, a higher score indicates less tax burden on investors. 
Govspend: The score the host country received for its government spending. $\beta_{\mathrm{GOVSPEND}}>0$ : A measure of the amount of government expenditure in the host country, a higher score indicates less government spending therefore less risk of budget deficits, sovereign debt problems, and crowding out of the private sector.

Bizfree: The score the host country received for its business freedom. $\beta_{\mathrm{BIZFREE}}>0$ : A measure of the government's regulation of business, a higher score indicates greater efficiency in starting, operating, and closing a business.

Labrfree: The score the host country received for its labor freedom. $\beta_{\mathrm{LABRFREE}}>0$ : A measure of the framework regulating the host country's labor market, a higher score gives indicates greater freedom from regulations such as minimum wages, severance requirements, and hiring and working hours.

Mntrfree: The score the host country received for its monetary freedom. $\beta_{\text {MNTRFRE }}>0$ : A measure of price stability through inflation and price controls; a higher score indicates less government intervention that distorts market activity.

Trdfree: The score the host country received for its trade freedom. $\beta_{\mathrm{TRDFREE}}>0$ : A measure of the presence of tariff and non-tariff barriers; a higher score indicates less cost associated with imports and exports.

Investfree: The score the host country received for its investment freedom. $\beta_{\text {INVESTFREE }}>0$ : A measure of the freedom of capital flows; a higher score indicates greater ease for investment capital to flow without restriction into different investment activities and across borders therefore giving investors more confidence as to the liquidity of their investment.

Finfree: The score the country received for its financial freedom. $\beta_{\text {FINFREE }}>0$ :A measure of banking efficiency and the banking industry's independence from the government in the host country; a higher score indicates less government intervention and regulation, more development in financial and capital markets, and increased openness to competition.

\section{Other factors:}

Conflict: A dummy variable where $1=$ Presence of armed conflict; $0=$ No armed conflict $\beta_{\mathrm{CONFLICT}}<0$ : The presence of internal geopolitical unrest could result in disturbances to production and consumption.

Econsanc: A dummy variable where $1=$ Existing economic sanctions on the host country by another country; $0=$ No economic sanctions, $\beta_{\text {ECONSANC }}<0$ : The presence of economic sanctions on the host country by another country could result in added instability or the direct restriction of investment in the host country.

More specifically, our estimated model is given by equation (2):

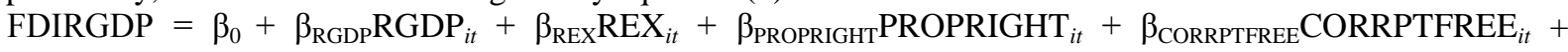

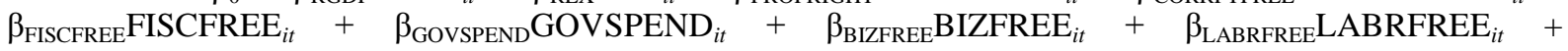

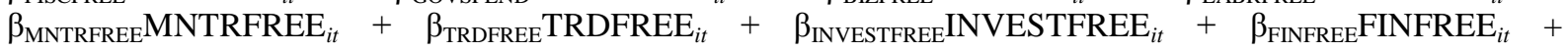
$\beta_{\text {CONFLICT }}$ ONFLICT $_{i t}+\beta_{\text {ECONSANC }_{\text {ECONSANC }}+\varepsilon}+\varepsilon$

\section{Methodology}

A fixed effects regression was used to analyze panel data across eight ASEAN member countries including Cambodia, Indonesia, Laos, Malaysia, Philippines, Singapore, Thailand, and Vietnam (Brunei was not included due to a lack of data for the time period). According to Baltagi ([12]), panel data provides more informative results through greater variability, less collinearity between the independent variables, and relatively more degrees of freedom. In addition, panel data provide many advantages in empirical analysis because the time series dimension is enhanced by the number of cross sections, thus enhancing the likelihood that the test statistics have a normal distribution in the limit. A common characteristic of panel data is that its time series dimension is generally shorter than a time series of a single crosssection. The dataset used in this study ranges sixteen years across eight cross-sections providing a sizable number of observations.

Similar to Ramirez (see [11]), the stacked model was estimated using the least squares method with fixed-effects crosssection (SUR) weights to account for time-invariant country characteristics and other economic factors such as market size. He argues that significant economic events occurring in developed countries affect FDI flows to all countries in Latin America, thereby causing cross-country correlations among error terms. A similar occurrence is likely in ASEAN countries. To determine whether the fixed effects method is appropriate (rather than the OLS pooled model), a redundant fixed effects test (incorporated in Eviews 8.0) was undertaken on the basic fixed effects model; the crosssection $F$ value of 4.94 ( $p$-value $=0.0001$ ) is highly significant, confirming that the fixed effects model is superior to the stacked regression model. Similarly, a Hausman (correlated random effects) test was undertaken to determine whether the fixed effects model (FEM) is superior to the random effects model (REM). The null hypothesis is that the two models do not differ substantially. The computed chi-square value of 11.162 (p-value: 0.04) suggests that the null hypothesis can be rejected at the 5 percent level of significance, thus the FEM model is preferred to the REM. In other words, the REM is not appropriate because the random error terms are likely correlated with one or more regressors.

Lags are also included on certain independent variables to account for economic factors and econometric concerns such as potential simultaneity. For instance, when firms look for growing consumer markets in which to invest, they look to the size of the market, its GDP or GDP per capita more specifically. Because economic indicators are not reported until 
the following economic period, it takes at least until the data is reported for firms to confirm quantitatively that the market is growing, and therefore their investment is lagged by at least this amount of time. Additionally, because real GDP is the denominator of the ratio that is the dependent variable, the real GDP is lagged in the estimation to avoid any heterogeneity. Furthermore, a log of the lagged FDI variable was included in the estimation to account for habit and persistence effects. The economic rationale is that firms with investments in host countries must continue to invest capital in order to continue operating. Also, the characteristics that attracted FDI in the previous year are likely similar in the current year. Therefore the annual relationship between FDI inflows for a given country is not random. Lastly, time series regressions often contain correlated residuals with their own lagged values. To account for this issue, a firstorder autoregressive element is incorporated into the model.

In general, they were the macroeconomic indicators such as GDP that required a lag. While a similar situation would apply to firms waiting for changes in foreign investment policies, the index components used in this study do not account for policy changes until at least the following period therefore it is inherently lagged.

\section{Data}

For data, the study uses the World Bank as a resource for macroeconomic panel data for the countries mentioned above. On occasion, the IMF, and UNCTAD databases were also used. Data for Myanmar posed more challenges, as databases such as the World Bank and even the EIU believe the country has a history of falsely reporting their statistics (see [13]). In this case, the quantitative analysis was limited to the countries mentioned above and was related qualitatively to Myanmar through the policies that it has implemented in its Foreign Investment Law of 2012.

Though the Index of Economic Freedom is very helpful, certain additions were necessary as not all of the components for every country are given back to 1995 . For instance, the labor freedom component did not have given any scores for any countries for the period 1995-2004 therefore some revisions were necessary. In this case, the Economic Freedom of the World Index, published by the Fraser Institute was also very helpful as many of its own components are similar; however, until 2000; this index was only on a five-year basis. Therefore, in the graded countries, the 1995 score was given and then a constant yearly change was applied to reach the 2005 score. In the case that the countries were not graded by this alternative index, the 2005 score was applied to the previous 10 years to prevent lost observations for other variables during this time period. This was necessary for Cambodia, Laos and Vietnam. Fortunately, in the case of these three countries, there is minimal variation of this particular variable for the years that were given by the index therefore it can be inferred that the previous decade would be similar.

Lastly, there are two dummy variables representing armed conflicts in the region and sanctions on the country. The armed conflicts data is from the Department of Peace and Conflict Research at the Uppsala Universitet. The variable accounts for both government and non-government associated armed conflict. The sanction variable is based on the Peterson Institute for International Economics, which provides a timeline of global economic sanctions.

A summary of the descriptive statistics can be found in the appendix.

\section{Results}

Results for five estimations are given in table 2 below. As previously mentioned, the results were found using the least squares method with white period standard errors and covariances. The fixed-effect estimations below estimate the relationship between FDI inflows as a ratio to real GDP and each independent variable, with the 4th and 5th estimations further including the dummy variables econsanc and conflict. Additionally, a logarithmic function was imposed on all of the independent variables except for the dummy variables. This follows the expectation that none of the relationships between the independent variables and FDI inflows are linear.

The first thing to note is that, with some exceptions, almost all coefficients are in the expected direction, especially for those variables that were found to be statistically significant. The lagged real GDP was found to be statistically significant in all regressions except for the second where the switch to the standard deviation of the exchange rate was also found to be insignificant. The positive significance of the lagged real GDP suggests that increased market size in the host country in the period prior to the MNE's investment attracts FDI flows therefore suggesting that firms are attracted to larger consumer bases. For instance, in the first regression, a $1 \%$ increase in the real GDP in the previous year increases the ratio of FDI inflows to real GDP by .55 percentage points, holding all other variables constant. In the case of regressions 3-5, real GDP is also found to be statistically significant with similar effects on FDI inflows. The slightly lower coefficient in the second regression may suggest the presence of negative bias between real GDP and the standard deviation of the real exchange rate. In this case, heteroscedasticity could also be present. As the market size 
increases (an increase in real GDP), the corresponding currency is likely to become more liquid and stable, thereby decreasing standard deviation.

Interestingly, the lagged real exchange rate was found to be statistically significant whereas the standard deviation of the real exchange rate was not in the second regression. One would expect that firms would consider the stability of the exchange rate to be of more concern than the real exchange rate, especially given that most of the currencies considered in this study are very inexpensive on a unit-by-unit basis compared with the US dollar. However, according to the results below, a statistically significant and negative relationship was found between the real exchange rate and FDI flows. For instance, in the third regression, a $1 \%$ increase in the real exchange rate (a depreciation of the host country's currency) would decrease FDI inflows by .15 percentage points, holding all other variables constant. A possible explanation could be that firms believe they can increase their profits from their investment in the host country if the host country's currency appreciates in value against the US dollar. The statistical significance of the last economic independent variable, the lagged FDI inflows, suggests that countries that attract FDI in the previous year would likely attract FDI in the current year. For instance, a $1 \%$ increase in FDI inflows in the previous year would increase FDI inflows in the current year by .43 percentage points (third regression). The inclusion of this variable in each estimation accounts for the heterogeneity that would otherwise bias the results.

With respect to the economic freedom variables, only the property rights variable (fifth regression), the government spending variable (first regression), the business freedom variable (fourth regression), the trade freedom variable (fourth regression), and the investment freedom variable (first and fourth regressions) were found to be statistically significant. A note to be kept in mind is that the index provides scores based on the overall component in the host country and does not separate conditions for domestic investors and conditions for foreign investors. In the case of the property rights variable, a $1 \%$ increase in the score the host country received for its protection of property rights would increase FDI inflows by .74 percentage points, holding all other variables constant. This variable strongly represents the first component of Dunning's OLI framework, Ownership, and therefore the statistical significance of this variable is not surprising as MNEs should give considerable attention to the protection of their property in host countries. Somewhat surprising, though not statistically significant, is the positive relationship with the freedom from corruption variable. This may suggest, as discussed in the introduction, that corruption may not always be disadvantageous to MNEs. For instance, a firm would be better off if it can register their business in the host country more quickly through a corrupttype agreement with the registration ministry rather than wait the seemingly long registration period. Though this would be considered in the corruption grade, it is this type of corruption that ironically can have a positive effect. Also surprising is the statistical significance of the government spending variable while the fiscal freedom variable was found not to be statistically significant. Generally, it would be in a MNE's interest to avoid taxes to the best of their ability and to endorse government spending. While government spending is often used to recognize the status of a country's infrastructure or school system, it also includes military expenditures. In the case of Southeast Asian countries, military expenditure could translate to armed conflict which would detract from FDI inflows, as is represented below. Furthermore, the Heritage foundation believes that government spending can cause budget deficits which ultimately have a negative effect on the overall economy.

One of the stronger relationships was found between FDI inflows and the business freedom variable. This variable represents the overall efficiency of the government in regulating business. For instance, the score assigned by the Heritage Foundation captures, among other similar measurements, the cost and time necessary to start a business, obtain licenses and registrations, and close a business. The results show that for a $1 \%$ increase in the business freedom score, FDI inflows would increase by 1.19 percentage points, holding all other variables constant. The last two economic freedom variables that were found to be statistically significant were trade freedom and investment freedom. The trade freedom variable, a score awarded to each country based on their tariff rates and non-tariff barriers affecting imports and exports of goods and services, was surprisingly found to be negatively related to FDI inflows. A possible explanation for this finding could be that the countries that impose higher tariff rates and non-tariff barriers are those that already receive higher FDI inflows and thus present a reverse causation effect. On the other hand, the investment freedom variable was found to be statistically significant and positively related in both the first and fourth regressions, as expected. The investment freedom variable, based on the score the country receives for the ease with which investors can transfer their capital resources, is unlike the other economic freedom variables in that it more directly addresses the issues specific to foreign investors. For instance, it gives consideration to the variation in regulations applied to foreign investors compared with domestic investors. Therefore, a $1 \%$ increase in the score the host country receives on its investment freedom would increase FDI flows by roughly .5 percentage points, holding all other variables constant.

Lastly, as can be seen at the bottom of the table, the adjusted R2, the F-statistic, and the Durbin-Watson show that the independent variables, overall, are good indicators of FDI inflows. An adjusted R2 of .7 shows that 70\% of the variance in FDI inflows is explained by the included independent variables. The F-statistics shows that, except for the final estimation, the variables are a good fit and finally, the Durbin-Watson statistic around 2 shows that there is no evidence of first order autocorrelation in any of the estimations. 


\section{Conclusion}

This study conducted an econometric analysis on panel data from Southeast Asian Countries for the period 1995-2011 with the aim of finding significant determining factors of FDI inflows to these countries. Using a fixed-effects regression, the analysis considered factors ranging across economic indicators, scores in the ten components measured in the Index of Economic Freedom, and the presence of economic sanctions and armed conflict. Though there were a few exceptions, the results obtained were generally as expected and can be explained both in economic and theoretical terms.

Table 1: Estimation results, dependent variable: logfdirgdp (t-statistics shown below coefficients in parentheses).

\begin{tabular}{|c|c|c|c|c|c|}
\hline Regressions & 1 & 2 & 3 & 4 & 5 \\
\hline \multirow[t]{2}{*}{$\mathrm{C}$} & -2.86 & -3.52 & -13.42 & -16.55 & -20.40 \\
\hline & $(-0.41)$ & $(-0.89)$ & $(-2.03)$ & $(-4.25)$ & $(-2.85)$ \\
\hline \multirow[t]{2}{*}{$\operatorname{logRGDP}(-1)$} & 0.55 & 0.30 & 0.41 & 0.66 & 0.65 \\
\hline & $(5.29)$ & $(1.28)$ & $(3.37)$ & (3.63) & $(2.15)$ \\
\hline \multirow[t]{2}{*}{$\log \operatorname{REX}(-2)$} & -0.19 & & -0.15 & -0.26 & -0.20 \\
\hline & $(-5.04)$ & & $(-3.25)$ & $(-3.66)$ & $(-1.80)$ \\
\hline \multirow[t]{2}{*}{ logSTDEV_REX(-2) } & & 0.07 & & & \\
\hline & & $(0.81)$ & & & \\
\hline \multirow[t]{2}{*}{$\log \mathrm{FDI}(-1)$} & 0.37 & 0.32 & 0.43 & 0.42 & -0.04 \\
\hline & $(1.94)$ & $(2.07)$ & $(3.90)$ & $(3.44)$ & $(-0.12)$ \\
\hline \multirow[t]{2}{*}{ logPROPRIGHT } & 0.11 & & & & 0.74 \\
\hline & $(0.50)$ & & & & $(3.26)$ \\
\hline \multirow[t]{2}{*}{ logCORRPTFREE } & & 0.11 & & & \\
\hline & & $(0.36)$ & & & \\
\hline \multirow[t]{2}{*}{ logFISCFREE } & & -0.22 & & & 0.09 \\
\hline & & $(-0.39)$ & & & $(0.21)$ \\
\hline \multirow[t]{2}{*}{$\log G O V S P E N D(-1)$} & -2.46 & -0.73 & & & 0.87 \\
\hline & $(-2.11)$ & $(-1.01)$ & & & $(0.76)$ \\
\hline \multirow[t]{2}{*}{$\operatorname{logBIZFREE}$} & & & & 1.19 & \\
\hline & & & & $(3.71)$ & \\
\hline \multirow[t]{2}{*}{ logLABRFREE } & & & 0.30 & & \\
\hline & & & $(0.22)$ & & \\
\hline \multirow[t]{2}{*}{ logMNTRFREE } & & & 0.42 & & \\
\hline & & & $(1.37)$ & & \\
\hline \multirow[t]{2}{*}{ logTRDFREE } & & & & -0.94 & \\
\hline & & & & $(-2.53)$ & \\
\hline \multirow[t]{2}{*}{ logINVESTFREE } & 0.48 & & & 0.46 & \\
\hline & $(2.13)$ & & & (3.04) & \\
\hline \multirow[t]{2}{*}{ logFINFREE } & & & 0.50 & & \\
\hline & & & $(0.91)$ & & \\
\hline \multirow[t]{2}{*}{ CONFLICT } & & & & & 0.13 \\
\hline & & & & & $(0.88)$ \\
\hline \multirow[t]{2}{*}{ ECONSANC } & & & & 0.31 & \\
\hline & & & & $(3.08)$ & \\
\hline \multirow[t]{2}{*}{$\mathrm{AR}(1)$} & -0.15 & -0.09 & -0.21 & -0.28 & 0.26 \\
\hline & $(-0.88)$ & $(-0.54)$ & $(-1.90)$ & $(-3.73)$ & $(0.84)$ \\
\hline $\operatorname{Adj}^{2}$ & 0.71 & 0.70 & 0.71 & 0.76 & 0.69 \\
\hline F-Statistic & 18.94 & 18.03 & 18.65 & 23.11 & 16.13 \\
\hline D.W. & 2.01 & 2.01 & 2.03 & 2.08 & 1.97 \\
\hline
\end{tabular}

Overall, trends in the region are promising for economic growth in general and growth of FDI inflows in particular. Myanmar has the opportunity to experience strong economic growth largely influenced by capital from abroad. However, to achieve this growth, Myanmar must first address key economic and political issues that may very well override the recently enacted investment laws, thereby reducing their effectiveness in attracting FDI inflows. For example, the presence of economic sanctions as well as risk induced by internal conflicts and natural disasters could render the implementation of the new investment law irrelevant. The presence and history of economic sanctions taints the picture that foreign firms see of a country, and often restricts investment altogether. The latter resulting in a net loss 
for all potential parties involved. Firms cannot simply bypass the direct restriction of capital flows to countries under economic sanctions. Myanmar should strive for the full removal of sanctions which are highly correlated with the presence of ongoing armed conflicts in the country. The presence of which is a significant burden to the progress that Myanmar has achieved in the last few years and could also hinder its attractiveness to investors moving forward.

Furthermore, the inherent risk from natural disasters should improve over time with the development of the country's infrastructure; however, this risk factor cannot be directly affected by political reforms and will remain a source of uncertainty for investors. Lastly, to attain the level of economic growth and development attained by the other countries studied, Myanmar must address economic and institutional factors in which they remain an outlier. For instance, the country's 2012 score of just 0 for investment freedom represents a significant constraint in its ability to attract future capital resources for growth and development.

Assuming that these institutional obstacles can be addressed in a meaningful fashion, Myanmar should then concentrate on those factors that appear to correlate most strongly with increased FDI inflows to other ASEAN countries. According to the findings above, the positive and statistically significant economic indicator variables are the lagged real GDP and the lagged real exchange rate. While Myanmar's market is not particularly large, a relatively large population and therefore a large potential labor force and consumer base would likely drive the country's GDP significantly higher in the coming years. In this case, speculation on future growth may prove to be of greater importance to MNEs rather than the market size per se in the previous period. However, the rationale still applies that market size is an important factor in determining FDI inflows.

With respect to Myanmar's real exchange rate, the country's recent move away from a fixed rate has resulted in a significant real depreciation, which according to the results found in this study, should have a negative effect on FDI inflows. Furthermore, with the switch to the market float, the rate lost considerable stability. While the fluctuation in the real exchange rate was not found to be statistically significant in this study, theory still suggests that a stable exchange rate is relevant to a MNE's decision to invest.

Additionally, many economic freedom variables were found to be statistically significant, including: Property Rights, Government Spending, Business Freedom, Trade Freedom and Investment Freedom. The statistical significance of many of the economic freedom components confirm this study's hypothesis that these index-based variables contain strong explanatory power and can be stronger indicators than either investment policies or institutional factors alone. Furthermore, the significance of these components suggests that it is the overall investment climate which attracts MNEs. With respect to these variables, Myanmar should concentrate its resources toward enforcing property rights. Its current score of only 10 is far below 43, the average score of the countries in this study over the time period. Myanmar's next area of concentration should be with respect to government spending. Myanmar's 2012 score of 96.8 is only slightly higher than the sample's average of 87.8. While the Heritage Foundation suggests this score is very good, and that government spending is only $10.4 \%$ of GDP, the military's decreasing role in the government should enable the country to decrease its military expenditures, thus freeing resources for more productive areas such as education and infrastructure.

One area that requires drastic improvement in order to attract FDI inflows is the degree of business freedom within the country. Myanmar's 2012 score of only 20 is far below the sample's average of 62 . Though its recent implementation of the Foreign Investment Law and corresponding rules should drastically improve the regulatory environment, efficient application of the policy may take a few more years. Lastly, the improvement of its investment freedom score is vital to attracting FDI inflows.

Myanmar has been presented with a unique opportunity to promote its economic growth and development forward. Before this can be achieved, Myanmar must first overcome the substantial economic and institutional obstacles mentioned above that will prevent its economy from attaining its growth potential. Second, the rationale underlying the inclusion of the freedom variables also applies to Myanmar's approach to its policies in general. Now that the government has successfully designed investment laws to attract FDI inflows, it must enforce these laws consistently and transparently--otherwise their existence will be irrelevant.

\section{Descriptive statistics and data tables}

A table outlining the descriptive statistics for the variables included in this study, country-specific descriptive statistics, and a correlation matrix can be found in the data tables and descriptive statistics section in the appendix.

With respect to the data, there are a few notable findings. For instance, the mean FDI inflows as a percentage of GDP over the time period was found to be 5.15\%. However, Singapore's average FDI inflows ratio was $16.23 \%$, roughly two standard deviations higher than the mean for the sample. This is likely due to Singapore's role as an international financial hub for Southeast Asia though Singapore's mean absolute real GDP is significantly smaller than other countries in the sample. 
In addition, the correlation between many of the index variables is also of concern. One might argue that a country would be likely to receive similar scores on their business freedom and investment freedom, or government spending and fiscal freedom. Interestingly, these examples only received correlations of .71 and .29, respectively. More interestingly is the high correlation between business freedom and property rights of .87. A potential explanation is that in countries inefficient in regulating businesses are also likely to regulate property laws inefficiently. Furthermore, these variables also tend to have higher correlations with other variables in the index indicating that these two variables are strong representatives of the overall economic freedom in the countries studied. These correlations were considered prior to estimating the regressions.

Lastly, few ASEAN member countries had economic sanctions imposed upon them resulting in the very low mean seen below. Unfortunately, this variable is not expected to be strongly related to FDI inflows due to the characteristics of the dataset.

Table 2: Descriptive statistics (all countries)

\begin{tabular}{|c|c|c|c|c|c|c|c|c|c|c|c|c|c|c|c|c|}
\hline & 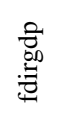 & 韋 & 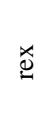 & 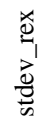 & 苋 & 总 & 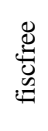 & 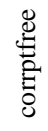 & 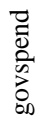 & 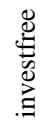 & 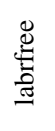 & 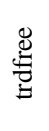 & $\begin{array}{l}\overrightarrow{0} \\
.00 \\
\overline{0} \\
0 \\
0\end{array}$ & $\begin{array}{l}\text { 异 } \\
\text { 莺 }\end{array}$ & 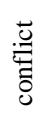 & 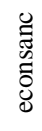 \\
\hline ฐ్ & $\begin{array}{l}\vec{\infty} \\
\hat{n} \\
\stackrel{n}{n} \\
\vec{n}\end{array}$ & $\begin{array}{c}\stackrel{0}{+} \\
\pm \\
\infty \\
\stackrel{\infty}{\infty} \\
\infty\end{array}$ & 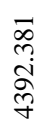 & $\begin{array}{l}\overrightarrow{0} \\
+ \\
\infty \\
\infty \\
\infty \\
-\end{array}$ & $\begin{array}{l}\stackrel{1}{*} \\
\text { gे } \\
\text { id }\end{array}$ & 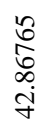 & $\begin{array}{l}\stackrel{+}{n} \\
\stackrel{n}{n} \\
\stackrel{n}{r}\end{array}$ & 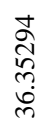 & $\begin{array}{l}\text { त̂ } \\
\text { bo } \\
\infty \\
\infty \\
\infty\end{array}$ & $\begin{array}{l}\stackrel{0}{1} \\
\overrightarrow{0} \\
\ddot{f} \\
\dot{f}\end{array}$ & 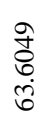 & 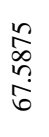 & 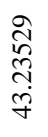 & 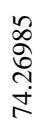 & $\begin{array}{l}\underset{+}{+} \\
\stackrel{\nabla}{0} \\
\stackrel{0}{0}\end{array}$ & $\begin{array}{l}\stackrel{\circ}{=} \\
\frac{\sigma}{\sigma} \\
0\end{array}$ \\
\hline 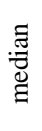 & $\frac{n}{\stackrel{n}{\sigma}}$ & $\begin{array}{l}0 \\
1 \\
+ \\
\infty \\
\infty \\
\infty\end{array}$ & 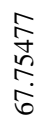 & $\begin{array}{l}\mathbb{0} \\
\stackrel{0}{0} \\
\stackrel{\circ}{0}\end{array}$ & $n$ & in & $\stackrel{n}{i}$ & $\stackrel{\infty}{\sim}$ & $\hat{\infty}$ & $\frac{n}{f}$ & $\begin{array}{l}\infty \\
\infty \\
0 \\
\delta \\
0 \\
\dot{\sigma}\end{array}$ & $\begin{array}{l}0 \\
\infty \\
0\end{array}$ & ஜి & $\overrightarrow{6}$ & 0 & 0 \\
\hline$\stackrel{×}{\leftrightarrows}$ & 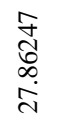 & 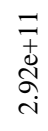 & $\begin{array}{l} \pm \\
\text { J } \\
\text { N } \\
\text { n }\end{array}$ & 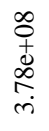 & 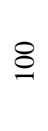 & 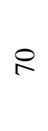 & 家 & ప & 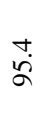 & \& & $\begin{array}{l}\hat{\infty} \\
\hat{\alpha}\end{array}$ & \& & \& & $\kappa$ & $N$ & - \\
\hline 志 & $\begin{array}{l}\underset{i}{n} \\
\stackrel{\mathbb{n}}{i}\end{array}$ & 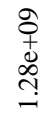 & 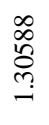 & $\frac{\vec{N}}{\stackrel{5}{\Omega}}$ & के & $\stackrel{0}{ }$ & ָָ & $\stackrel{0}{=}$ & $\stackrel{+}{\sim}$ & $\stackrel{\varrho}{ }$ & $\stackrel{\bullet}{\ddot{f}}$ & $\cong$ & $\stackrel{0}{ }$ & $\stackrel{\infty}{\stackrel{\infty}{ }}$ & 0 & 0 \\
\hline $\begin{array}{l}\overrightarrow{0} \\
\overrightarrow{0} \\
\vec{n}\end{array}$ & $\begin{array}{l}\hat{N} \\
\stackrel{N}{\infty} \\
\stackrel{i}{i} \\
\text {. }\end{array}$ & $\begin{array}{l}0 \\
+ \\
0 \\
0 \\
0 \\
r\end{array}$ & $\begin{array}{l}\hat{N} \\
\text { ñ } \\
\text { तु } \\
\text { है }\end{array}$ & 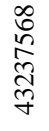 & $\begin{array}{l}\vec{n} \\
\hat{n} \\
\infty \\
\infty\end{array}$ & 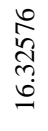 & 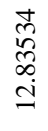 & $\begin{array}{l}\frac{\hat{0}}{n} \\
\stackrel{+}{d}\end{array}$ & $\begin{array}{l}0 \\
\delta \\
\delta \\
\frac{\delta}{n} \\
\dot{n}\end{array}$ & 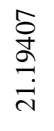 & $\begin{array}{l}\stackrel{\infty}{\Xi} \\
\overrightarrow{8} \\
\dot{ \pm}\end{array}$ & $\begin{array}{l}\frac{1}{2} \\
\hat{2} \\
\stackrel{2}{2}\end{array}$ & 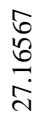 & $\begin{array}{l}n \\
\infty \\
n \\
n \\
=\end{array}$ & $\begin{array}{l}\text { t } \\
\text { J } \\
\stackrel{+}{+} \\
\dot{0}\end{array}$ & 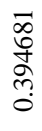 \\
\hline 嗮 & 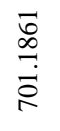 & 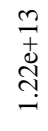 & $\begin{array}{l}\hat{\sigma} \\
\text { } \\
\tilde{\sigma} \\
\hat{\sigma}\end{array}$ & 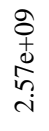 & $\underset{\infty}{\infty}$ & $\begin{array}{l}\text { D } \\
\infty \\
\text { n }\end{array}$ & 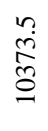 & 导 & 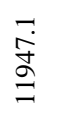 & 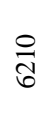 & 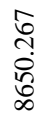 & $\frac{a}{a}$ & $\begin{array}{l}\stackrel{D}{\infty} \\
\infty \\
i n\end{array}$ & $\stackrel{\hat{8}}{0}$ & $\bar{\gamma}$ & $\stackrel{\sim}{*}$ \\
\hline 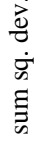 & $\begin{array}{l}\stackrel{2}{N} \\
\infty \\
\text { के }\end{array}$ & $\begin{array}{l}\tilde{T} \\
\stackrel{+}{ \pm} \\
\tilde{D} \\
\dot{0}\end{array}$ & \begin{tabular}{l}
8 \\
o \\
+ \\
8 \\
\multirow{8}{*}{} \\
i.
\end{tabular} & $\begin{array}{l}\text { I } \\
+ \\
\text { N } \\
\\
\text { N }\end{array}$ & 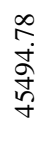 & 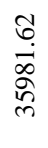 & 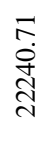 & 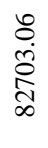 & 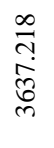 & 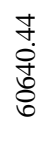 & 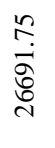 & 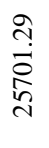 & 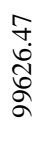 & 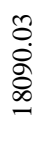 & 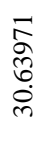 & 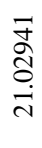 \\
\hline ô & 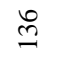 & 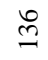 & 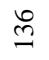 & 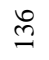 & 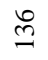 & 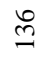 & 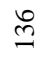 & 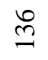 & 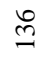 & $\stackrel{\bigodot}{ٍ}$ & 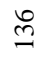 & 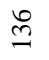 & 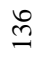 & $\stackrel{0}{\sim}$ & 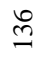 & $\stackrel{0}{2}$ \\
\hline
\end{tabular}

Table 3: Cambodia descriptive statistics

\begin{tabular}{|c|c|c|c|c|c|c|c|c|}
\hline & mean & median & Max & $\min$ & std. dev. & sum & sum sq. dev. & obs \\
\hline $\begin{array}{l}\text { fdirgdp } \\
\text { rgdp }\end{array}$ & $\begin{array}{c}5.78 \\
5070000000 . \\
00\end{array}$ & $\begin{array}{c}6.03 \\
4570000000 . \\
00\end{array}$ & $\begin{array}{c}10.04 \\
8450000000 . \\
00\end{array}$ & $\begin{array}{c}1.80 \\
2570000000 . \\
00\end{array}$ & $\begin{array}{c}2.23 \\
2010000000 \\
00\end{array}$ & $\begin{array}{c}98.28 \\
86100000000 . \\
00\end{array}$ & $\begin{array}{c}79.62 \\
64400000000000000000 \\
.00\end{array}$ & 17 \\
\hline $\begin{array}{c}\text { rex } \\
\text { stdev_re }\end{array}$ & 3995.04 & 3904.60 & 5531.21 & 1996.98 & 1042.48 & 67915.71 & 17388151.00 & 17 \\
\hline$x$ & 827023.90 & 348286.60 & 6843885.00 & 17977.17 & 1660396.00 & 14059406.00 & 44100000000000.00 & 17 \\
\hline bizfree & 50.39 & 55.00 & 55.00 & 39.50 & 6.51 & 856.60 & 678.24 & 17 \\
\hline finfree & 54.71 & 50.00 & 70.00 & 50.00 & 8.74 & 930.00 & 1223.53 & 17 \\
\hline $\begin{array}{l}\text { fiscfree } \\
\text { corrptfre }\end{array}$ & 91.42 & 91.40 & 91.70 & 90.90 & 0.23 & 1554.20 & 0.87 & 17 \\
\hline e & 26.00 & 30.00 & 30.00 & 10.00 & 6.13 & 442.00 & 602.00 & 17 \\
\hline
\end{tabular}




\begin{tabular}{|c|c|c|c|c|c|c|c|c|}
\hline $\begin{array}{l}\text { govspen } \\
\mathrm{d} \\
\text { investfre }\end{array}$ & 92.33 & 91.80 & 94.50 & 90.40 & 1.31 & 1569.60 & 27.28 & 17 \\
\hline $\mathrm{e}$ & 51.18 & 50.00 & 60.00 & 50.00 & 3.32 & 870.00 & 176.47 & 17 \\
\hline labrfree & 44.24 & 43.90 & 46.30 & 43.60 & 0.80 & 752.10 & 10.24 & 17 \\
\hline $\begin{array}{l}\text { trdfree } \\
\text { proprigh }\end{array}$ & 53.65 & 62.80 & 70.00 & 15.00 & 19.70 & 912.00 & 6206.52 & 17 \\
\hline $\mathrm{t}$ & 30.00 & 30.00 & 30.00 & 30.00 & 0.00 & 510.00 & 0.00 & 17 \\
\hline mntrfree & 75.38 & 78.00 & 87.00 & 62.10 & 8.38 & 1281.40 & 1124.39 & 17 \\
\hline $\begin{array}{l}\text { conflict } \\
\text { econsan }\end{array}$ & 0.29 & 0.00 & 1.00 & 0.00 & 0.47 & 5.00 & 3.53 & 17 \\
\hline $\mathrm{c}$ & 0.88 & 1.00 & 1.00 & 0.00 & 0.33 & 15.00 & 1.76 & 17 \\
\hline & mean & median & Max & $\min$ & std. dev. & sum & sum sq. dev. & $\mathrm{ob}$ \\
\hline & & & & & & & & s. \\
\hline fdirgdp & 0.83 & 1.35 & 2.92 & -2.76 & 1.66 & 14.09 & 43.99 & 17 \\
\hline rgdp & $\begin{array}{c}20300000000 \\
0.00\end{array}$ & $\begin{array}{c}18700000000 \\
0.00\end{array}$ & $\begin{array}{c}29200000000 \\
0.00\end{array}$ & $\begin{array}{c}15600000000 \\
0.00\end{array}$ & $\begin{array}{c}4370000000 \\
0.00\end{array}$ & $\begin{array}{c}346000000000 \\
0.00\end{array}$ & $\begin{array}{c}30500000000000000000 \\
000.00\end{array}$ & 17 \\
\hline rex & 7733.39 & 8087.38 & 13097.62 & 813.54 & 3877.84 & 131467.70 & 241000000.00 & 17 \\
\hline $\begin{array}{l}\text { stdev_r } \\
\text { ex }\end{array}$ & 9922538.00 & 7470425.00 & 50704214.00 & 214935.80 & 11910294.00 & 169000000.00 & 2270000000000000.00 & 17 \\
\hline bizfree & 53.15 & 55.00 & 55.00 & 46.60 & 3.22 & 903.60 & 166.12 & 17 \\
\hline finfree & 37.65 & 40.00 & 50.00 & 30.00 & 8.31 & 640.00 & 1105.88 & 17 \\
\hline fiscfree & 78.81 & 79.40 & 83.00 & 73.10 & 2.26 & 1339.80 & 81.64 & 17 \\
\hline $\begin{array}{l}\text { corrptfr } \\
\text { ee }\end{array}$ & 20.41 & 20.00 & 28.00 & 10.00 & 5.28 & 347.00 & 446.12 & 17 \\
\hline $\begin{array}{c}\text { govspe } \\
\text { nd }\end{array}$ & 88.59 & 89.10 & 95.40 & 76.50 & 4.13 & 1506.10 & 272.45 & 17 \\
\hline $\begin{array}{c}\text { investfr } \\
\text { ee }\end{array}$ & 47.06 & 50.00 & 70.00 & 30.00 & 17.14 & 800.00 & 4702.94 & 17 \\
\hline labrfree & 50.90 & 50.94 & 52.78 & 49.10 & 0.73 & 865.22 & 8.60 & 17 \\
\hline trdfree & 71.68 & 73.00 & 77.90 & 45.00 & 7.49 & 1218.50 & 898.43 & 17 \\
\hline $\begin{array}{c}\text { proprig } \\
\mathrm{ht}\end{array}$ & 37.06 & 30.00 & 50.00 & 30.00 & 9.85 & 630.00 & 1552.94 & 17 \\
\hline $\begin{array}{c}\text { mntrfre } \\
\mathrm{e}\end{array}$ & 69.45 & 71.30 & 74.60 & 49.40 & 6.60 & 1180.60 & 696.24 & 17 \\
\hline conflict & 0.53 & 1.00 & 1.00 & 0.00 & 0.51 & 9.00 & 4.24 & 17 \\
\hline $\begin{array}{c}\text { econsa } \\
\text { nc }\end{array}$ & 0.41 & 0.00 & 1.00 & 0.00 & 0.51 & 7.00 & 4.12 & 17 \\
\hline
\end{tabular}

\begin{tabular}{|c|c|c|c|c|c|c|c|c|}
\hline & mean & median & $\max$ & $\min$ & std. dev. & sum & sum sq. dev. & obs \\
\hline fdirgdp & 3.67 & 3.62 & 8.53 & 0.25 & 2.42 & 62.44 & 93.85 & 17 \\
\hline $\operatorname{rgdp}$ & $\begin{array}{c}2230000000 . \\
00\end{array}$ & $\begin{array}{l}2060000000 . \\
00\end{array}$ & $\begin{array}{l}3720000000 . \\
00\end{array}$ & $\begin{array}{c}1280000000 . \\
00\end{array}$ & $\begin{array}{c}753000000.0 \\
0\end{array}$ & $\begin{array}{l}37900000000 . \\
00\end{array}$ & $\begin{array}{c}9070000000000000000 . \\
00\end{array}$ & 17 \\
\hline rex & 6709.63 & 9317.36 & 10655.17 & 80.42 & 4080.52 & 114063.0 & 266000000.00 & 17 \\
\hline$\underset{x}{\text { stdev_re }}$ & 7557617.00 & 3378546.00 & 31809890.00 & 238631.40 & 8362837.00 & 128000000.00 & 1120000000000000.00 & 17 \\
\hline bizfree & 45.98 & 40.00 & 60.80 & 40.00 & 8.67 & 781.70 & 1203.91 & 17 \\
\hline finfree & 14.12 & 10.00 & 30.00 & 10.00 & 6.18 & 240.00 & 611.76 & 17 \\
\hline fiscfree & 60.32 & 70.60 & 80.10 & 32.20 & 18.92 & 1025.40 & 5724.61 & 17 \\
\hline$\underset{\mathrm{e}}{\text { corrptfre }}$ & 14.00 & 10.00 & 33.00 & 10.00 & 7.04 & 238.00 & 794.00 & 17 \\
\hline $\begin{array}{c}\text { govspen } \\
\mathrm{d}\end{array}$ & 88.29 & 89.70 & 92.80 & 81.30 & 3.29 & 1501.00 & 173.19 & 17 \\
\hline $\begin{array}{c}\text { investfre } \\
\mathrm{e}\end{array}$ & 20.00 & 25.00 & 30.00 & 10.00 & 9.84 & 340.00 & 1550.00 & 17 \\
\hline labrfree & 60.88 & 61.30 & 63.50 & 49.90 & 3.01 & 1035.00 & 144.88 & 17 \\
\hline trdfree & 64.06 & 66.00 & 81.00 & 55.60 & 7.95 & 1089.00 & 1011.66 & 17 \\
\hline $\begin{array}{l}\text { proprigh } \\
\mathrm{t}\end{array}$ & 10.88 & 10.00 & 20.00 & 10.00 & 2.64 & 185.00 & 111.76 & 17 \\
\hline mntrfree & 57.88 & 62.80 & 80.40 & 13.80 & 17.45 & 984.00 & 4869.95 & 17 \\
\hline conflict & 0.00 & 0.00 & 0.00 & 0.00 & 0.00 & 0.00 & 0.00 & 17 \\
\hline $\begin{array}{c}\text { econsan } \\
\mathrm{c}\end{array}$ & 0.00 & 0.00 & 0.00 & 0.00 & 0.00 & 0.00 & 0.00 & 17 \\
\hline
\end{tabular}


Table 6: Malaysia descriptive statistics

\begin{tabular}{|c|c|c|c|c|c|c|c|c|}
\hline & mean & median & $\max$ & $\min$ & std. dev. & sum & sum sq. dev. & $\begin{array}{l}\mathrm{ob} \\
\mathrm{s} .\end{array}$ \\
\hline fdirgdp & 3.52 & 3.71 & 5.13 & 0.06 & 1.48 & 59.91 & 35.06 & 17 \\
\hline $\operatorname{rgdp}$ & $\begin{array}{c}11000000000 \\
0.00\end{array}$ & $\begin{array}{c}10500000000 \\
0.00\end{array}$ & $\begin{array}{c}15400000000 \\
0.00\end{array}$ & $\begin{array}{c}7420000000 \\
0.00\end{array}$ & $\begin{array}{c}2540000000 \\
0.00\end{array}$ & $\begin{array}{c}187000000000 \\
0.00\end{array}$ & $\begin{array}{c}10300000000000000000 \\
000.00\end{array}$ & 17 \\
\hline rex & 3.52 & 3.68 & 4.13 & 2.52 & 0.50 & 59.81 & 4.03 & 17 \\
\hline $\begin{array}{c}\text { stdev_r } \\
\text { ex }\end{array}$ & 10206148.00 & 8875556.00 & 30073545.00 & 1201321.00 & 8320767.00 & 174000000.00 & 1110000000000000.00 & 17 \\
\hline bizfree & 75.05 & 70.00 & 85.00 & 67.60 & 7.60 & 1275.90 & 924.90 & 17 \\
\hline finfree & 41.18 & 40.00 & 50.00 & 30.00 & 9.28 & 700.00 & 1376.47 & 17 \\
\hline fiscfree & 80.33 & 80.90 & 84.60 & 74.10 & 2.88 & 1365.60 & 132.30 & 17 \\
\hline $\begin{array}{l}\text { corrptfr } \\
\text { ee }\end{array}$ & 52.76 & 51.00 & 70.00 & 45.00 & 6.78 & 897.00 & 735.06 & 17 \\
\hline $\begin{array}{c}\text { govspe } \\
\text { nd }\end{array}$ & 80.86 & 81.30 & 85.50 & 74.20 & 3.57 & 1374.60 & 203.82 & 17 \\
\hline $\begin{array}{c}\text { investfr } \\
\text { ee }\end{array}$ & 39.71 & 40.00 & 70.00 & 30.00 & 11.52 & 675.00 & 2123.53 & 17 \\
\hline labrfree & 71.23 & 70.23 & 79.20 & 68.47 & 2.28 & 1210.97 & 83.08 & 17 \\
\hline trdfree & 71.47 & 73.00 & 78.70 & 55.00 & 6.45 & 1215.00 & 666.14 & 17 \\
\hline $\begin{array}{c}\text { proprig } \\
\text { ht }\end{array}$ & 57.35 & 50.00 & 70.00 & 50.00 & 9.70 & 975.00 & 1505.88 & 17 \\
\hline$\underset{\mathrm{e}}{\mathrm{mntrfre}}$ & 79.83 & 79.90 & 82.80 & 76.60 & 2.10 & 1357.10 & 70.50 & 17 \\
\hline conflict & 0.00 & 0.00 & 0.00 & 0.00 & 0.00 & 0.00 & 0.00 & 17 \\
\hline $\begin{array}{c}\text { econsa } \\
\text { nc }\end{array}$ & 0.00 & 0.00 & 0.00 & 0.00 & 0.00 & 0.00 & 0.00 & 17 \\
\hline
\end{tabular}

Table 7: Philippines descriptive statistics

\begin{tabular}{|c|c|c|c|c|c|c|c|c|}
\hline & mean & median & Max & $\min$ & std. dev. & sum & sum sq. dev. & $\begin{array}{l}\mathrm{ob} \\
\mathrm{s} .\end{array}$ \\
\hline fdirgdp & 1.55 & 1.61 & 3.17 & 0.26 & 0.80 & 26.32 & 10.14 & 17 \\
\hline $\operatorname{rgdp}$ & $\begin{array}{c}95900000000 \\
.00\end{array}$ & $\begin{array}{c}90700000000 \\
.00\end{array}$ & $\begin{array}{c}13400000000 \\
0.00\end{array}$ & $\begin{array}{c}68000000000 \\
.00\end{array}$ & $\begin{array}{c}21100000000 \\
.00\end{array}$ & $\begin{array}{c}163000000000 \\
0.00\end{array}$ & $\begin{array}{c}71200000000000000000 \\
00.00\end{array}$ & 17 \\
\hline rex & 43.29 & 47.94 & 55.09 & 19.52 & 11.90 & 735.96 & 2264.89 & 17 \\
\hline $\begin{array}{l}\text { stdev_r } \\
\text { ex }\end{array}$ & 10027073.00 & 8686373.00 & 29710956.00 & 1134281.00 & 8217794.00 & 170000000.00 & 1080000000000000.00 & 17 \\
\hline bizfree & 55.07 & 55.00 & 70.00 & 43.40 & 6.48 & 936.20 & 671.96 & 17 \\
\hline finfree & 48.82 & 50.00 & 50.00 & 30.00 & 4.85 & 830.00 & 376.47 & 17 \\
\hline fiscfree & 75.82 & 75.90 & 78.80 & 73.00 & 2.11 & 1288.90 & 71.20 & 17 \\
\hline $\begin{array}{l}\text { corrptfr } \\
\text { ee }\end{array}$ & 26.53 & 26.00 & 36.00 & 10.00 & 5.46 & 451.00 & 476.24 & 17 \\
\hline $\begin{array}{l}\text { govspe } \\
\text { nd }\end{array}$ & 89.29 & 88.90 & 91.20 & 87.90 & 1.09 & 1517.90 & 19.16 & 17 \\
\hline $\begin{array}{c}\text { investfr } \\
\text { ee }\end{array}$ & 43.53 & 50.00 & 50.00 & 30.00 & 8.62 & 740.00 & 1188.24 & 17 \\
\hline labrfree & 54.81 & 54.55 & 59.17 & 50.70 & 2.61 & 931.75 & 109.06 & 17 \\
\hline trdfree & 68.86 & 77.00 & 79.80 & 42.00 & 12.55 & 1170.60 & 2520.22 & 17 \\
\hline $\begin{array}{c}\text { proprig } \\
\text { ht }\end{array}$ & 46.47 & 50.00 & 70.00 & 30.00 & 17.66 & 790.00 & 4988.24 & 17 \\
\hline$\underset{\mathrm{e}}{\text { mntrfre }}$ & 76.12 & 76.70 & 79.30 & 72.70 & 1.90 & 1294.00 & 57.86 & 17 \\
\hline conflict & 1.06 & 1.00 & 2.00 & 1.00 & 0.24 & 18.00 & 0.94 & 17 \\
\hline $\begin{array}{c}\text { econsan } \\
\text { c }\end{array}$ & 0.00 & 0.00 & 0.00 & 0.00 & 0.00 & 0.00 & 0.00 & 17 \\
\hline
\end{tabular}

Table 8: Singapore descriptive statistics

\begin{tabular}{|c|c|c|c|c|c|c|c|c|}
\hline & mean & median & $\max$ & $\min$ & std. dev. & sum & sum sq. dev. & $\begin{array}{l}\text { ob } \\
\text { s. }\end{array}$ \\
\hline fdirgdp & 16.28 & 14.65 & 27.86 & 7.07 & 6.72 & 276.76 & 721.59 & 17 \\
\hline $\operatorname{rgdp}$ & $\begin{array}{c}11400000000 \\
0.00\end{array}$ & $\begin{array}{l}10300000000 \\
0.00\end{array}$ & $\begin{array}{c}17400000000 \\
0.00\end{array}$ & $\begin{array}{c}7250000000 \\
0.00\end{array}$ & $\begin{array}{c}3160000000 \\
0.00\end{array}$ & $\begin{array}{c}194000000000 \\
0.00\end{array}$ & $\begin{array}{c}16000000000000000000 \\
000.00\end{array}$ & 17 \\
\hline rex & 1.67 & 1.68 & 1.93 & 1.31 & 0.21 & 28.40 & 0.69 & 17 \\
\hline $\begin{array}{l}\text { stdev_r } \\
\text { ex }\end{array}$ & 10214198.00 & 8884043.00 & 30087659.00 & 1203942.00 & 8324564.00 & 174000000.00 & 1110000000000000.00 & 17 \\
\hline bizfree & 99.18 & 100.00 & 100.00 & 96.70 & 1.21 & 1686.10 & 23.34 & 17 \\
\hline finfree & 63.53 & 70.00 & 70.00 & 50.00 & 8.62 & 1080.00 & 1188.24 & 17 \\
\hline fiscfree & 86.05 & 87.80 & 91.10 & 80.60 & 4.05 & 1462.80 & 262.52 & 17 \\
\hline
\end{tabular}




\begin{tabular}{|c|c|c|c|c|c|c|c|c|}
\hline $\begin{array}{l}\text { corrptfr } \\
\text { ee }\end{array}$ & 91.65 & 92.00 & 94.00 & 87.00 & 2.03 & 1558.00 & 65.88 & 17 \\
\hline $\begin{array}{c}\text { govspe } \\
\text { nd }\end{array}$ & 91.68 & 91.30 & 95.30 & 88.10 & 2.03 & 1558.50 & 65.93 & 17 \\
\hline $\begin{array}{l}\text { investfr } \\
\text { ee }\end{array}$ & 86.47 & 90.00 & 90.00 & 75.00 & 5.80 & 1470.00 & 538.24 & 17 \\
\hline labrfree & 89.91 & 93.08 & 98.90 & 72.62 & 9.19 & 1528.48 & 1352.66 & 17 \\
\hline trdfree & 85.53 & 85.00 & 90.00 & 83.00 & 3.08 & 1454.00 & 152.24 & 17 \\
\hline $\begin{array}{c}\text { proprig } \\
\text { ht }\end{array}$ & 90.00 & 90.00 & 90.00 & 90.00 & 0.00 & 1530.00 & 0.00 & 17 \\
\hline $\begin{array}{c}\text { mntrfre } \\
\text { e }\end{array}$ & 87.92 & 88.00 & 93.00 & 80.90 & 3.14 & 1494.70 & 157.51 & 17 \\
\hline conflict & 0.00 & 0.00 & 0.00 & 0.00 & 0.00 & 0.00 & 0.00 & 17 \\
\hline $\begin{array}{c}\text { econsa } \\
n c\end{array}$ & 0.00 & 0.00 & 0.00 & 0.00 & 0.00 & 0.00 & 0.00 & 17 \\
\hline
\end{tabular}

Table 9: Thailand descriptive statistics

\begin{tabular}{|c|c|c|c|c|c|c|c|c|}
\hline & mean & median & $\operatorname{Max}$ & $\min$ & std. dev. & sum & sum sq. dev. & $\begin{array}{l}\text { ob } \\
\text { s. }\end{array}$ \\
\hline fdirgdp & 3.38 & 3.13 & 6.54 & 1.23 & 1.43 & 57.47 & 32.56 & 17 \\
\hline rgdp & 14700000000 & 14100000000 & 18800000000 & 11200000000 & 2640000000 & 250000000000 & 11200000000000000000 & 17 \\
\hline & 0.00 & 0.00 & 0.00 & 0.00 & 0.00 & 0.00 & 000.00 & \\
\hline rex & 36.26 & 38.40 & 44.50 & 23.20 & 6.25 & 616.41 & 625.69 & 17 \\
\hline $\begin{array}{c}\text { stdev_r } \\
\text { ex }\end{array}$ & 10069041.00 & 8713085.00 & 29851951.00 & 1154189.00 & 8266985.00 & 171000000.00 & 1090000000000000.00 & 17 \\
\hline bizfree & 70.63 & 70.00 & 73.80 & 69.90 & 1.21 & 1200.70 & 23.26 & 17 \\
\hline finfree & 52.94 & 50.00 & 70.00 & 50.00 & 6.86 & 900.00 & 752.94 & 17 \\
\hline fiscfree & 74.84 & 74.80 & 75.50 & 74.20 & 0.41 & 1272.30 & 2.72 & 17 \\
\hline $\begin{array}{l}\text { corrptfr } \\
\text { ee }\end{array}$ & 37.35 & 33.00 & 70.00 & 28.00 & 12.51 & 635.00 & 2505.88 & 17 \\
\hline $\begin{array}{c}\text { govspe } \\
\text { nd }\end{array}$ & 91.02 & 91.10 & 93.10 & 88.00 & 1.22 & 1547.30 & 23.74 & 17 \\
\hline $\begin{array}{c}\text { investfr } \\
\text { ee }\end{array}$ & 48.82 & 50.00 & 70.00 & 30.00 & 16.16 & 830.00 & 4176.47 & 17 \\
\hline labrfree & 71.52 & 73.60 & 77.70 & 61.08 & 5.53 & 1215.86 & 488.95 & 17 \\
\hline trdfree & 71.40 & 71.60 & 77.80 & 64.80 & 4.60 & 1213.80 & 338.78 & 17 \\
\hline $\begin{array}{c}\text { proprig } \\
\text { ht }\end{array}$ & 63.53 & 70.00 & 90.00 & 45.00 & 16.08 & 1080.00 & 4138.24 & 17 \\
\hline $\begin{array}{c}\text { mntrfre } \\
\mathrm{e}\end{array}$ & 77.19 & 76.40 & 88.90 & 66.40 & 7.00 & 1312.30 & 783.21 & 17 \\
\hline conflict & 0.53 & 1.00 & 1.00 & 0.00 & 0.51 & 9.00 & 4.24 & 17 \\
\hline $\begin{array}{c}\text { econsa } \\
\text { nc }\end{array}$ & 0.00 & 0.00 & 0.00 & 0.00 & 0.00 & 0.00 & 0.00 & 17 \\
\hline
\end{tabular}

Table 10: Vietnam descriptive statistics

\begin{tabular}{|c|c|c|c|c|c|c|c|c|}
\hline & mean & median & Max & $\min$ & std. dev. & sum & sum sq. dev. & $\begin{array}{l}\mathrm{ob} \\
\mathrm{s} .\end{array}$ \\
\hline fdirgdp & 6.23 & 6.01 & 10.52 & 3.54 & 2.45 & 105.91 & 96.25 & 17 \\
\hline $\operatorname{rgdp}$ & $\begin{array}{c}41200000000 \\
.00\end{array}$ & $\begin{array}{c}38300000000 \\
.00\end{array}$ & $\begin{array}{c}66500000000 \\
.00\end{array}$ & $\begin{array}{c}22300000000 \\
.00\end{array}$ & $\begin{array}{c}14200000000 \\
.00\end{array}$ & $\begin{array}{c}700000000000 \\
.00\end{array}$ & $\begin{array}{c}32200000000000000000 \\
00.00\end{array}$ & 17 \\
\hline rex & 16616.24 & 14110.95 & 35264.14 & 9489.47 & 6872.61 & 282476.10 & 756000000.00 & 17 \\
\hline $\begin{array}{l}\text { stdev_r } \\
\text { ex }\end{array}$ & 92283570.00 & 49656455.00 & $\begin{array}{c}378000000.0 \\
0\end{array}$ & 31490483.00 & 93095532.00 & $\begin{array}{c}1570000000.0 \\
0\end{array}$ & 139000000000000000.00 & 17 \\
\hline bizfree & 47.29 & 40.00 & 61.70 & 40.00 & 10.19 & 804.00 & 1661.79 & 17 \\
\hline finfree & 30.00 & 30.00 & 30.00 & 30.00 & 0.00 & 510.00 & 0.00 & 17 \\
\hline fiscfree & 62.62 & 63.40 & 76.10 & 42.80 & 12.53 & 1064.50 & 2513.27 & 17 \\
\hline $\begin{array}{l}\text { corrptfr } \\
\text { ee }\end{array}$ & 22.12 & 26.00 & 28.00 & 10.00 & 7.00 & 376.00 & 783.76 & 17 \\
\hline $\begin{array}{c}\text { govspe } \\
\text { nd }\end{array}$ & 80.71 & 79.10 & 90.30 & 73.40 & 4.65 & 1372.10 & 346.00 & 17 \\
\hline $\begin{array}{c}\text { investfr } \\
\text { ee }\end{array}$ & 28.53 & 30.00 & 30.00 & 15.00 & 4.24 & 485.00 & 288.24 & 17 \\
\hline labrfree & 65.35 & 64.10 & 70.00 & 64.10 & 1.98 & 1110.90 & 62.68 & 17 \\
\hline trdfree & 54.06 & 51.00 & 68.90 & 44.60 & 7.88 & 919.00 & 992.84 & 17 \\
\hline $\begin{array}{c}\text { proprig } \\
\text { ht }\end{array}$ & 10.59 & 10.00 & 15.00 & 10.00 & 1.66 & 180.00 & 44.12 & 17 \\
\hline $\begin{array}{c}\text { mntrfre } \\
\text { e }\end{array}$ & 70.39 & 69.30 & 86.50 & 55.20 & 8.64 & 1196.60 & 1194.60 & 17 \\
\hline conflict & 0.00 & 0.00 & 0.00 & 0.00 & 0.00 & 0.00 & 0.00 & 17 \\
\hline $\begin{array}{c}\text { econsan } \\
\text { c }\end{array}$ & 0.24 & 0.00 & 1.00 & 0.00 & 0.44 & 4.00 & 3.06 & 17 \\
\hline
\end{tabular}


Table 11: Correlation matrix

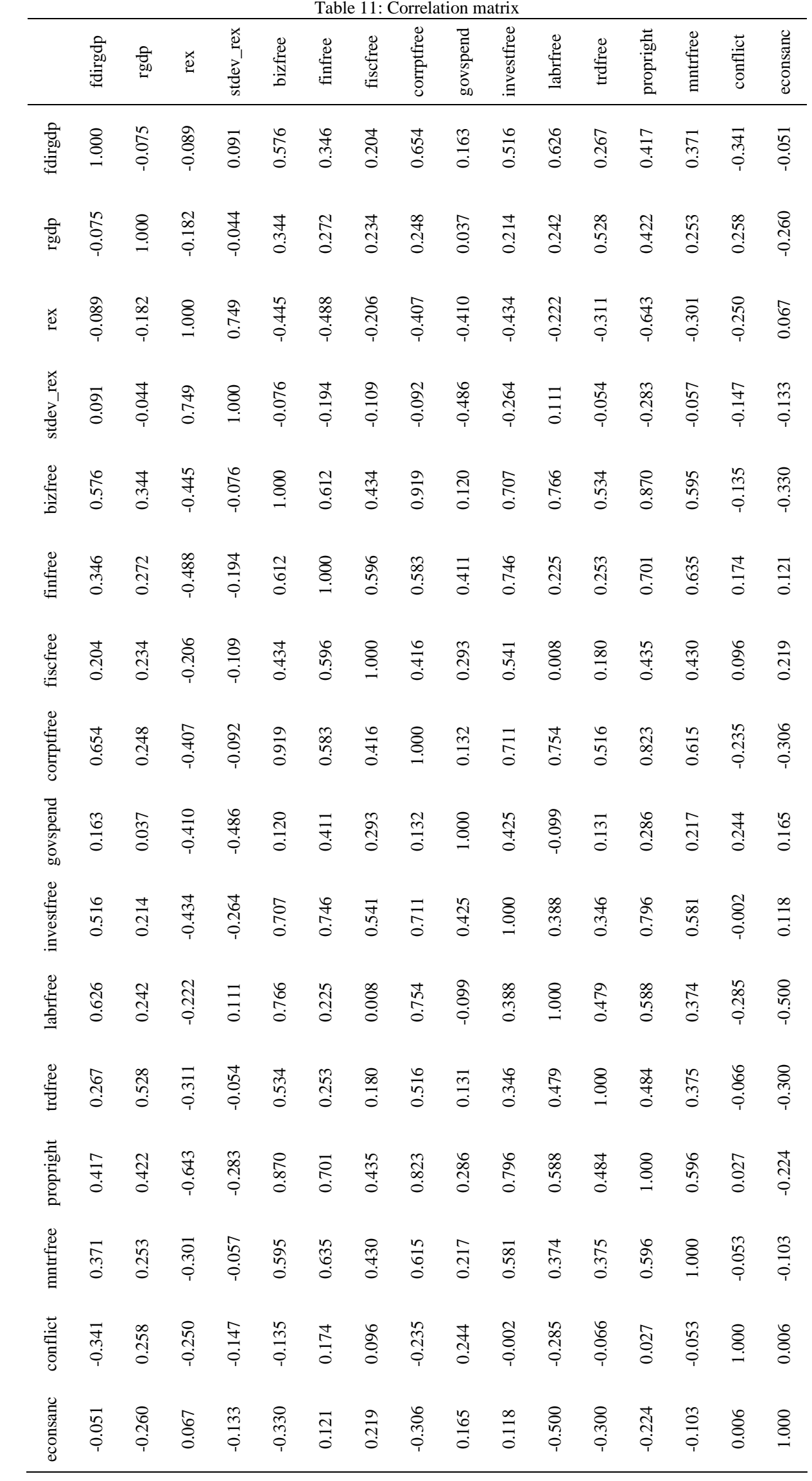




\section{References}

[1] Groff, Stephen P. "Asian Development Bank (ADB)." Myanmar Has the Potential to Become Asia's Rising Star. Web. 24 Nov. 2012.

[2] "Central Intelligence Agency." CIA. Web. 09 Feb. 2013.

[3] Dunning, John H. International Production and the Multinational Enterprise. London: Allen \&Unwin, 1981. Print.

[4] Larkin, Stuart. "Myanmar at the Crossroads: Rapid Industrial Development or De-industrialization." Http://www.networkmyanmar.org. 1 Jan. 2012. Web. 22 Nov. 2012. <http://networkmyanmar.org/images/stories/PDF13/Stuart-Larkin.pdf>.

[5] QuanHoang, Vuong, Dam Van Nhue, Daniel Van Houtte, andTran Tri Dung. "The Entrepreneurial Facets as Precursor to Vietnam's Economic Renovation in 1986." The IUP Journal of Entrepreneurship Development VIII.4 (2011). Print.

[6] Soon Kim, Tan, Edwin Neo, and Jesse SantriaOeni. "Myanmar: Opportunities in Asia’s Last Frontier Economy." IE Insights 2 (2012).International Enterprise Singapore. Web. 28 Jan. 2013.

[7] Moran, Theodore H. Foreign Direct Investment and Development: The New Policy Agenda for Developing Countries and Economies in Transition. Washington, DC: Institute for International Economics, 1998. Print.

[8] O'Shea, Veronica, Tom Platts, Sally Austen, Richard Nelson, and Alastair Henderson. "Myanmar Introduces Foreign Investment Rules." Lexology. Herbert Smith Freehills, 5 Feb. 2013. Web. 14 Feb. 2013.

[9] Tonkin, Derek. "Transparency International and Myanmar: An Exercise in Futility." Http://www.networkmyanmar.org. 8 Dec. 2012. Web. 27 Jan. 2013. <http://networkmyanmar.org/images/stories/PDF13/ti-cpi-2012-rev.pdf>.

[10] De Mello, L.R., Jr., 1997. AForeign Direct Investment in Developing Countries and Growth: A Selective Survey, @ 34 (October): 1-34.

[11] Ramirez, Miguel D. "Economic and Institutional Determinants of FDI Flows to Latin America: A Panel Study." Trinity College Department of Economics.May 2010. Web. 5 Nov. 2012. <http://www.trincoll.edu/depts/econ/>.

[12] Baltagi, Badi H. Econometric Analysis of Panel Data. Chichester: Wiley, 1995. Print.

[13] EIU Country Report: Indonesia March 2013. Rep. London: Economist Intelligence Unit, 2013. Print. 